conference and the next in those with whom they have argued most keenly.

But some of the fall-out has been detectable and concrete. An example is the new Stockholm International Institute for Peace Research. This is an independent organization financed by the Swedish Government but, as the Prime Minister of Sweden told the conference at its opening session, it owes its existence to Pugwash.

The delegates came from nearly 40 countries, broadly representative as between East and West, and between advanced and developing nations. Indeed, one of the trends in recent years has been the increasing attendance from countries other than the UK, USA and USSR - though not at present including China. Representation from the USSR has always been high (it included Kapitza on this occasion); here Pugwash has probably been ahead even of conventional scientific conferences.

The work of the conference was done at many levels -in plenary sessions, in working groups, and in ad hoc committees. More than 70 invited or contributed papers were read, covering all aspects of science and world affairs, such as arms control and arms regulation; the resolution of current conflicts; the role of UNO international scientific programmes; assistance to developing nations; social responsibilities of scientists; the underlying reasons for conflict. Of course, no problems were solved; no doubt the final statements varied in real content in roughly inverse proportion to their political sensitivity. But there was a notable absence of complacency about the international situation or about the contribution of Pugwash. On the international scene an apparent détente between the "super-powers" comes at a time when "local" wars are perhaps more numerous than ever before. The conference was well aware of the instability of this situation, as the statement by the Continuing Committee shows.

The contribution of Pugwash in the future under its new President, Cockcroft, and chairman, Powell, will be by intensification of its own work. Conferences and study groups will be smaller but much more numerous, much more closely focused on particular problems, and much more professional in character. Perhaps even more important, the Pugwash movement must attract many more scientists-especially younger scientists-and must increase its budget. It is the only movement of its kind: the only independent international forum for scientists concerned about world affairs.

G. O. Jones

\section{Pugwash Statement}

The safeguards system of the International Atomic Energy Agency got a nod of approval at the 17th Pugwash conference which has just taken place in Ronneby, Sweden (see preceding story). In the report of the continuing committee, which describes what went on, some details are given of the discussion on the problems of disarmament. While welcoming the tabling of the draft non-proliferation treaty, the conference regretted the omission of Article 3, which covers safeguards. Fears about inspection should be allayed, as far as possible, by minimizing the intrusiveness of the inspection, and ultimately it would be better if the nuclear states were subject to the same inspection as the non-nuclear states. "The control system of the IAEA," the statement says, "appears to be entirely adequate for the required inspection." It goes on to say that because of the great importance of the nonproliferation treaty, countries should not impose conditions-such as other disarmament measures-on its acceptance. These are more likely to be successfully negotiated after the treaty is signed. One suggestion is that nuclear powers should undertake not to use nuclear weapons against states which have signed the treaty, which do not possess nuclear weapons and which are prepared to promise that there are no nuclear weapons on their territory.

The conference agreed that it is now possible to detect nuclear tests underground, so that there is no objection on technical grounds to extending the test ban treaty. The repeated outbreak of local wars not involving nuclear weapons alarmed the conference, and this statement warns of the dangers of the militarization of the oceans and of outer space, and of chemical and biological warfare. All nations were urged to adhere to the Geneva Protocol of 1925, and a formal treaty prohibiting the use and transport of chemical and biological weapons should be negotiated.

The conference agreed that all states should recognize the German Democratic Republic, and that both West and East Germany should be admitted to the United Nations without prejudicing the eventual reunification. The bombing of North Vietnam should be stopped immediately and unconditionally, peace negotiations should begin and a conference should be convened to establish a stable peace in South East Asia.

The conference returned to a discussion of a proposal previously made at Pugwash-the formation of an International Science Foundation within the UN to permit young scientists in developing countries to undertake research they would not otherwise be able to afford. The International Biological Programme seems to be going well in the developed countries but has so far failed in the underdeveloped countries for lack of funds. Too little is known, says the statement, about the production of essential foodstuffs in the tropies; the technical problems are linked with economic, religious and social ones. On a more optimistic note, the conference had hopes of the creation of what the statement calls "agro-industrial power complexes" in coastal deserts or in partly fertile areas. In essence, these would be large nuclear reactors producing electricity for desalination and fertilizer production.

\section{Task Force for COMSAT}

THe restrictions governing communications in the United States have now become so archaic and contradictory that the corporations in command of satellites, computers and cables must hesitate before taking logical steps ahead, lest they run foul of the law. The fairly young Communications Satellite Corporation (COMSAT) is probably the most hamstrung of all. At the moment it is waiting to hear from the Federal Communications Commission whether it can spend some of its capital of $\$ 200$ million to provide an experimental domestic satellite service for the United States. Worse still, the corporation will have to hang on until 1969 to know what part it is ultimately to play in the International Telecommunications 